\title{
A novel morphological type of siderite in the jamesonite paragenesis from Herja (Maramureş County, Romania)
}

\author{
Virgil GHIURCĂํㅜ \& Dana POP2* \\ ${ }^{1}$ Department of Geology, “Babeş-Bolyai” University, 1 Kogălniceanu St., 400084 Cluj Napoca, Romania \\ ${ }^{2}$ Mineralogical Museum, "Babeş-Bolyai”" University, 1 Kogălniceanu St., 400084 Cluj Napoca, Romania
}

Received January 2005; accepted November 2005

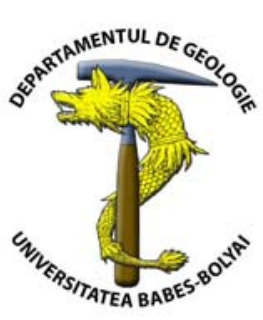

\begin{abstract}
The loose jamesonite felted masses found in several vein-type Miocene ore deposits in Romania, at Herja in particular, host a very rich and peculiar mineral assemblage. This study concerns a novel morphological type of loose siderite crystals identified in this paragenesis. Additional to their macroscopic and microscopic investigation, powder X-ray diffraction (XRPD) analysis was carried out. Based on XRPD patterns, some pseudoxehagonal prisms, up to $10 \mathrm{~mm}$ in size, black to dark brown in color, with rugged surfaces and microscopic mosaic-like structures, were proved to be siderite. The described morphological type of siderite represents a novelty for Herja ore deposits, possibly also for Romania and for the entire Carpathian region.
\end{abstract}

Key words: siderite, morphology, XRPD, jamesonite, paragenesis, Herja, Romania

\section{INTRODUCTION}

The Herja deposit belongs to the Baia Mare metallogenetic district and consists of a low-sulfidation type (Mârza et al., 2004) polymetallic ore ( $\mathrm{Zn}>\mathrm{Pb} \pm \mathrm{Cu}, \mathrm{Ag}$, $\mathrm{Au})$.

The mineralization is represented by an extensive Pannonian-age hydrothermal vein body system with a depth probably exceeding $1,000 \mathrm{~m}$ and a width of more than 1,200 $\mathrm{m}$. The veins are hosted by either sedimentary (Neogene, Paleogene) rocks, or by the Sarmatian-Pannonian subvolcanic body of pyroxene andesites and porphyritic quartz microdiorites (Cook and Damian, 1997).

One of the features of scientific interest related to the Herja ore deposit is represented by the so-called "plumosite" ("Federerz"), describing pockets of a loose felty matted mass of acicular crystals. Similar occurrences were described from other ore deposits in the Baia Mare region (such as Baia Sprie or Săsar), or other Miocene vein-type deposits from Romania (Udubaşa et al., 1993), but the bestdeveloped ones were those found at Herja and Baia Sprie. The mineralogical nature of "plumosite" has proved to be variable; at Herja, the detailed X-ray crystallographic investigation of Cook and Damian (1997) confirmed the presence of jamesonite as the dominant phase, representing the final stage in the evolution of the corresponding ore deposits (Udubaşa et al., 1993).

In the Herja ore deposit, the loose felted masses of acicular jamesonite fill-in, spherical-ovoidal or irregular, rarely elongated vugs and cavities, usually $15-25 \mathrm{~cm}$ in diameter, occasionally reaching $1 \mathrm{~m}$ in size. The jamesonite masses contain a very rich association of minerals, present as either idiomorphous crystals, or as globular aggregates (Ghiurcă, 2005). Most of them occur as "floaters" (or "loners"), i.e., fully terminated loose (non-fixed) crystals with apparently no point of attachment to the substrate (thus lacking rock matrix), showing well-defined crystal faces. Their sizes vary from $<1 \mathrm{~mm}$ up to $15 \mathrm{~cm}$. The assemblage contains both metallic (for example, sphalerite, tetrahedrite, chalcopyrite, pyrite, stibnite, semseyite, arsenopyrite) and non-metallic minerals (e.g., quartz, calcite, siderite, ankerite, barite, gypsum). A previous study (Moțiu et al., 1972) on single crystals and aggregates has identified the following minerals: quartz (as single and twined crystals, or aggregates between $0.03-1.2 \mathrm{~mm}$ in size), $\left(\mathrm{Fe}^{2+} \mathrm{Mn}\right) \mathrm{CO}_{3}$ - a manganoan variety of siderite, tetrahedrite (single crystals, $1-5$ $\mathrm{mm}$ in size), and sphalerite (single crystals, $0.8-3.5 \mathrm{~mm}$ in size).

Ghiurcă (2005) described several types of globular aggregates of idiomorphous crystals of calcite, siderite, ankerite and less commonly quartz, sphalerite and galena, showing a centrifugal growth pattern.

\section{SIDERITE IN THE JAMESONITE PARAGENESIS FROM HERJA}

Siderite is abundant in the jamesonite pockets where quartz is usually missing or subordinate. For decades, a wide range of morphological types of loose siderite aggregates and single crystals has been collected by the first author of this study.

A brief description of this selection follows, with an emphasis on the novel morphological type of single crystals. Except for the latter case, all the other types were defined as siderite only based on the physical properties and their response to dilute $\mathrm{HCl}$ (Cordua, 2000). 


\section{Types of aggregates}

1a. Massive globular and ovoidal aggregates $(1-5 \mathrm{~cm})$, black to brownish in color (Fig. 1). The constituent crystals are flattened, curved rhombohedra reaching several $\mathrm{mm}$ in length; they imprint a rugged aspect to the surface of the aggregate. In some cases 2 or 3 such ball-like aggregates are grouped together, forming lobate shapes. They may contain inclusions of acicular jamesonite microcrystals.

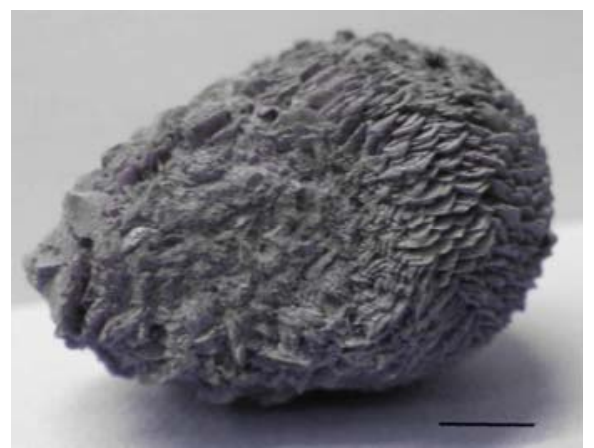

Fig. 1. Massive ovoidal siderite aggregate; scale bar: $1 \mathrm{~cm}$.

1b. Hollow, non-fixed brownish globular concretions (1 $-5 \mathrm{~cm}$ ), first described by Mârza et al. (2004) consist of concentric thin films ( $1-4 \mathrm{~mm}$ thick) of colloidal siderite which form a crust. Inside the void they sometimes have trapped loose rhombohedral siderite and minor jamesonite, sphalerite, marcasite and gypsum microcrystals, probably formed around large gas bubbles of high-density mineralizing fluids.

1c. Macrocrystalline ball-like aggregates $(0.5-1.2 \mathrm{~cm})$, black-grayish in color (Fig. 2), first described by Ghiurcă (2005). They produce rosettes of flat and partly curved wellseparated rhombohedral crystals. Their surface shows distinctive metallic bluish-reddish iridescence, due to a film of an unknown mineral. This siderite type may contain acicular and curved jamesonite microcrystals visible both in the interior and on the aggregate surfaces.

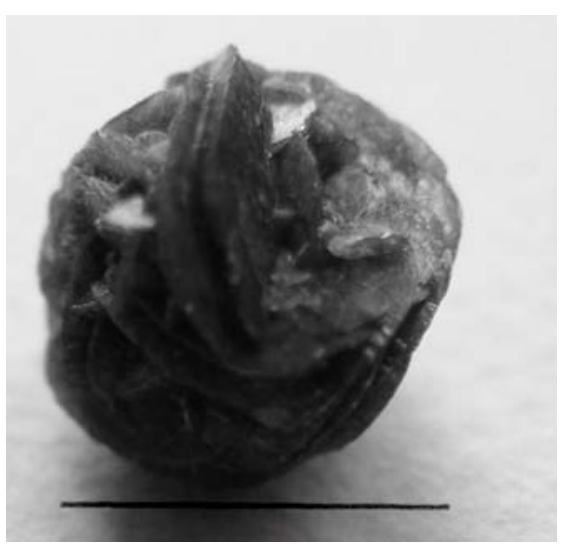

Fig. 2. Macrocrystalline ball-like siderite aggregate scale bar: $1 \mathrm{~cm}$.

\section{Types of single crystals}

2a. Rhombohedral microcrystals. A large number of less than $1 \mathrm{~mm}$ rhombohedral crystals ranging in colour from white to brown are present in the jamesonite paragenesis from Herja. The jamesonite microcrystalline inclusions are curved and belong to several morphological types described by Ghiurcă (1985a, 1985b, 1985c) and Ghiurcă and Moțiu (1986) (transitional, elliptic, ring-like, cylindrical etc.).
Mineralogically, we have defined them as siderite based on their morphological similarity with the manganoan variety identified by Moțiu et al. (1972). These consists of brownish, or sometimes white rhombohedral crystals, 0.5$1.8 \mathrm{~mm}$ in size, occasionally showing convex growth features; some aggregates show parallel intergrowths along the $c$ axis. The nature of this phase was defined by means of IR spectroscopy, spectral (emission) analysis data and X-ray powder diffraction (Moțiu et al., 1972). Similar microcrystals were identified in the hollow inner part of the globular concretions described by Mârza et al. (2004) (type $1 \mathrm{~b}$ above).

2b. Pseudohexagonal crystals, up to $1 \mathrm{~cm}$ in size. They represent a novel morphological type for the siderite crystals in the Herja ore deposit. Rădulescu and Dimitrescu (1966) mentioned scalenohedral siderite from hydrothermal deposits, in particular from Herja. In this ore deposit, such crystals may reach up to $0.5 \mathrm{~cm}$ in size; rhombohedral crystals of up to $1 \mathrm{~cm}$ were mentioned from the same locality (Szakáll, 2002). Based on the synthetic presentation of the various forms of siderite occurrences in Szakáll (2002), the pseudoxehagonal siderite crystals may represent a novelty for the whole Carpathian region.

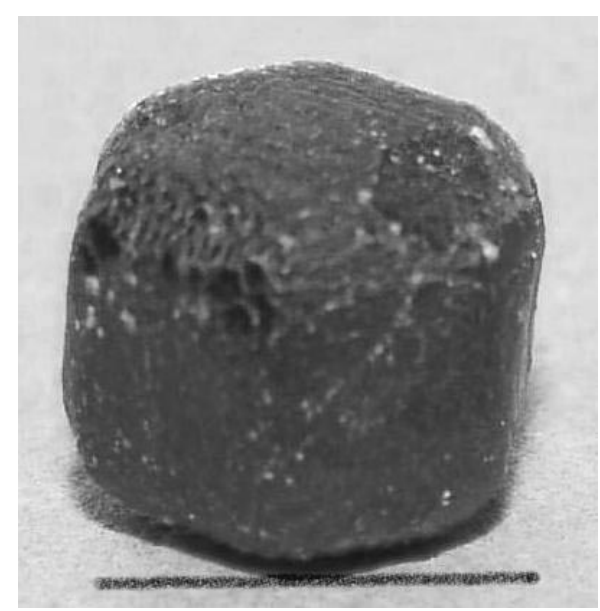

Fig. 3. Pseudohexagonal siderite crystal - view parallel to $c$ axis; scale bar: $1 \mathrm{~cm}$.

\section{THE NOVEL MORPHOLOGICAL TYPE - BRIEF MINERALOGICAL CHARACTERIZATION}

The newly identified type of siderite crystals is described below in terms of macroscopic, microscopic, and powder XRD features. The crystals with a blocky isometric habit consist of short dominant pseudoxehagonal prisms ending with poorly developed rhombohedra. They are black to dark brown in color and range from several $\mathrm{mm}$ up to about $1 \mathrm{~cm}$ in size (Figs. 3 and 4). Three crystal forms are noticeable, of which [110] and [001] are dominant, and [ $\overline{1} \overline{1} 1]$ is subordinate. This crystal morphology most closely resembles a form originating from Cornwall and presented in the atlas of Goldschmidt (1916; Band III, Tafel 107, Fig. 3) (Fig. 5 in the present study).

Some of the samples represent polycrystalline aggregates, with a large, central individual containing faces of smaller crystals penetrating its prism faces, i.e., the [110] forms (Fig. 6). The main crystal faces, especially representing the [001] form, are slightly curved and show a rugged surface, possibly pointing to mosaic structures. 




Fig. 4. Pseudohexagonal siderite crystal - view perpendicular to $c$ axis; scale bar: $1 \mathrm{~cm}$.

Under the petrographic microscope, the thin section perpendicular to the $c$ axis illustrates the presence of an apparently polycrystalline aggregate, more evident in crosspolarized light. The photomicrographs (taken under crossed polars and using blue filters to emphasize the internal structure) show several sharp but also uneven grain boundaries and little variation in the optical features (Figs. 7, 8). The differences in the optical appearance resulted from the small changes in the orientation of neighboring crystallites suggest mosaics in the case of the siderite crystals studied, probably related to structural defects. Some microscopic cracks are also visible (Fig. 8). According to Tsipursky and Buseck (1993) the presence of microfractures in large (apparently single) biogenic calcite crystals may also indicate mosaic structures.

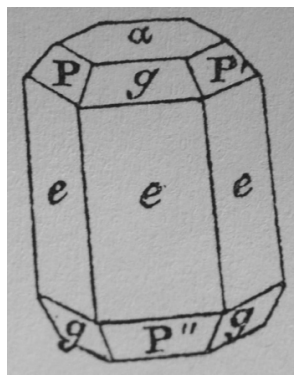

Fig. 5. Siderite from Cornwall (Fig. 3, Tafel 107, Band III; Goldschmidt, 1916).

The perfect fit of the $d(\AA)$ values between the sample studied and the JCPDS reference siderite documents the mineralogical assignment of the newly described morphological type (Table 1). However, there are striking differences concerning the relative intensities, which are probably related to a relatively poorer crystallinity (smaller coherent scattering domains) of the siderite from Herja as compared to the reference sample. Additionally, some analytical effects (grinding, calibration) should not be excluded.

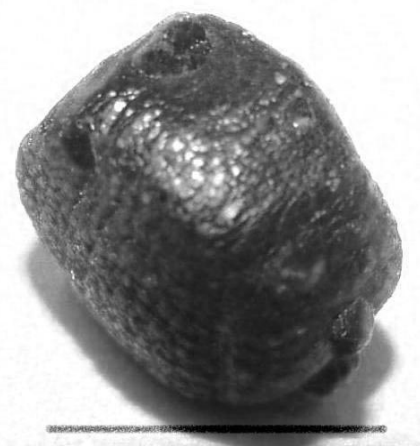

Fig. 6. Polycrystalline aggregate of pseudohexagonal siderite crystals; scale bar: $1 \mathrm{~cm}$.
Table 1. X-ray diffraction parameters of siderite.

\begin{tabular}{ccccc}
\hline & \multicolumn{2}{c}{$\begin{array}{c}\text { Siderite, Herja } \\
\text { (present study) }\end{array}$} & \multicolumn{2}{c}{ Siderite } \\
(JCPDS 29-069)
\end{tabular}

\section{GENETIC CONSIDERATIONS}

A similar genesis as in the case of the hollow, globular siderite concretions (Mârza et al., 2004) or of the globular aggregates of various mineralogical natures (Ghiurcă, 2005) is assumed for the newly identified type of siderite crystals. In particular, the formation of the hollow siderite concretions was considered similar to that of cave pearls, i.e., microcrystalline crusts forming around air bubbles in shallow cave pools (Mârza et al., 2004). In such karst environments, the growing speed is the same in all directions due to the fluid's supersaturation, the rounded shapes being naturally promoted. Small and/or occasional vibrations, even in environments without any water turbulence, prevent the cementation of the cave pearls to the pool's floor (Hill and Forti, 1997).

The isometric shape of the novel siderite type may be favored by the reduced sizes of its crystals: in the case of cave pearls, the smaller they are, the more rounded, as a consequence of larger surface area per unit weight. In the karst environment, monocrystalline growth takes place when saturated fluids are constantly supplied (Hill \& Forti, 1997).

The previous references on the jamesonite paragenesis from Herja suggested its formation in open spaces (small pools, or geodes) filled with circulating high-density (muddy, turbid) hydrothermal solutions, rich in gaseous phase. The dense fluids and the gas bubbles provided the 
floatability of the forming loose minerals. The isotropic crystallization stopped when the weight reached by the resulting crystals and aggregates determined their gravitational settlement at the bottom of the geode (Mârza et al., 2004). The loose jamesonite felted masses in suspension in the high-density fluids must have played an important role during the crystallization of the floaters, by providing a dense, but still porous and elastic substrate. This is proven by the common presence of jamesonite microcrystals included in other minerals, or at their surface, sometimes imprinting an allochromatic brown-blackish color to the light-colored ones.

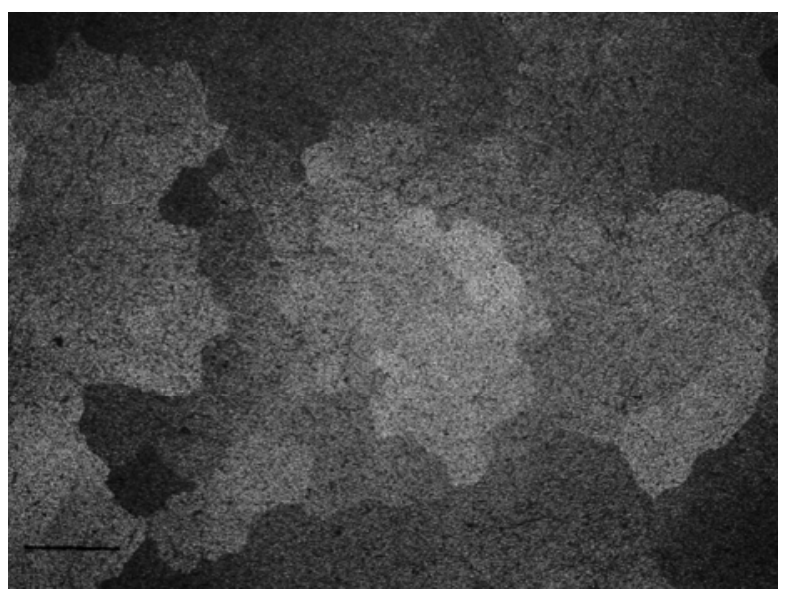

Fig. 7. Microphotograph of a pseudoxehagonal siderite crystal: mosaic structure; $\mathrm{N+}$, scale bar: $1 \mathrm{~mm}$.

The spherical or elliptical shape of the original geodes has played a major role in this process: all the investigated jamesonite-containing vein-type samples from Herja and other similar ore deposits were lacking loose crystals or aggregates, the associated minerals being fixed to the rock matrix. In the same time, no curved or ring jamesonite crystals were identified.

The pressurized supersaturated mineralizing fluids that led to the formation of the jamesonite paragenesis had complex chemistry, as proven by the large number of resulting mineral species. Two paragenetic types were defined by Mârza et al. (2004): one quartz-rich with common sulfides, and one carbonate-rich, without quartz and poor in sulfides (Mârza et al., 2004). The siderite under study was formed in the second type of environment, which is typical for the Herja Southern Group (Şălan - Clementina) vein system (Mârza et al., 2004).

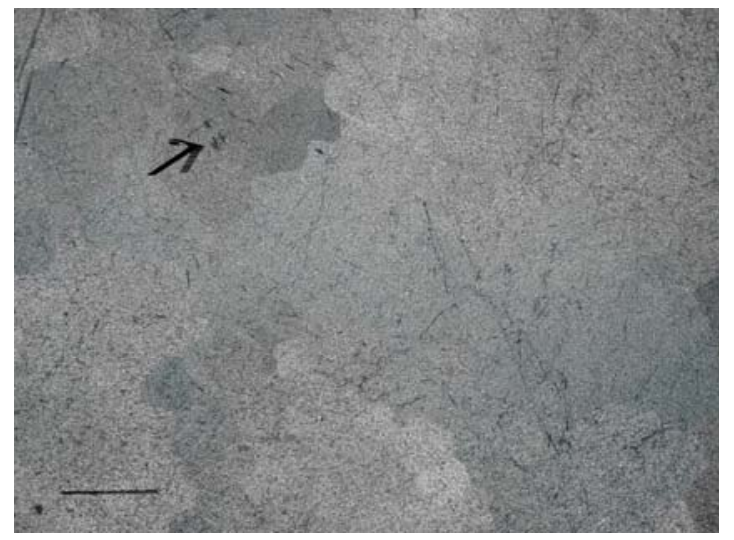

Fig. 8. Microphotograph of a pseudoxehagonal siderite crystal: arrow indicates microfractures (defective zones) $\mathrm{N}+$ scale bar: $1 \mathrm{~mm}$.
Relatively low temperatures of formation are assumed for the jamesonite paragenesis; Borcoş et al. (1975) indicated temperatures below $215^{\circ} \mathrm{C}$ for the formation of the $\mathrm{Pb}-\mathrm{Sb}$ sulfosalts, including jamesonite. The high diversity of crystal aggregates and habits may point to thermal variations recorded by the genetic environment (Moțiu et al., 1972). Formation at relatively low temperatures is also assumed (Udubaşa and Gorduza, 1980, in Udubaşa et al., 1992) for the jamesonite-containing spheroidal black and white aggregates of flattened rhombohedral calcite disposed "en échelon", reaching up to 7-8 $\mathrm{cm}$ in diameter (Udubaşa et al., 1992). However, variations of other genetic factors such as density, $\mathrm{pH}$, as well as solution kinetics and supersaturation (Hill and Forti, 1997) of the mineralizing fluids cannot be excluded as significant during the genetic processes.

\section{CONCLUSIONS}

1. A new morphological type of loose siderite crystals was identified in the jamesonite paragenesis from Herja (of hydrothermal origin). The crystals consist of short dominant pseudoxehagonal prisms ending with poorly developed rhombohedra. The forms [110] and [001] are dominant, while $[\overline{1} \overline{1} 1]$ is subordinate. This crystal feature may represent a novelty for Romania and even for the Carpathian region.

2. The jamesonite mineral association from geodes in vein-type Miocene deposits of Romania shows distinctive crystallographic, mineralogic, and genetic characteristics. A very rich association of non-fixed (loose) minerals, present as either idiomorphous crystals, or as globular aggregates has already been described. The quasi-isotropic crystalline growth must be related to specific genetic environments, such as open spaces (geodes) constantly supplied with supersaturated, high-density hydrothermal fluids. The jamesonite felted masses played an important role, as dense, but still porous and elastic substrates for the crystallization of the other minerals in the paragenesis. There are significant differences between the mineral associations of the geode-type vs. vein-type jamesonite-containing samples.

3. Detailed study of the jamesonite paragenesis, especially concerning microcrystals, may reveal other peculiar crystallographic features or rare mineralogical aspects. There are still unidentified mineral phases (Moțiu et al., 1972), e.g., a Fe, $\mathrm{Mn}, \mathrm{Mg}$ and $\mathrm{Ca}$ carbonate forming twin globular aggregates, as well as a $\mathrm{Fe}$ - and As- rich phase consisting of star-like crystals of black colour and metallic luster.

Acknowledgements. Contribution of prof. dr. Lucreția Ghergari (Department of Mineralogy) is valued for the suggestions related to the presence of mosaic crystals. The reviewers, conf. dr. Gh. Ilinca, and prof. dr. Bogdan Onac are acknowledged for their useful suggestions. Lecturer dr. Dan Andreica (Faculty of Physics) contributed with the XRPD measurement. Prof. dr. Sorin Filipescu and prof. dr. Ioan Bucur provided the digital photo equipment. Dr. Lesley Atkinson and prof. dr. Alan Bromley (PETROLAB, Redruth, UK) are acknowledged for the revision of the English version of the manuscript. The studied samples were donated by their owner (dr. V. Ghiurcă) to the Mineralogical Museum of the "Babeş-Bolyai" University. 


\section{R E F E R E N C E S}

Borcoş, M., Lang, B., Boştinescu, S. \& Gheorghiță, I. 1975, Neogene hydrothermal ore deposits in the volcanic Gutîi Mountains. III Dealul Crucii - Băiuț district. A. Herja, Baia Sprie and Şuior ore deposits. Revue Roumaine de Geologie, Geophysique et Geographie, serie Geologie, 19: 21-35.

Cook, N.J., Damian, G. 1997, New data on "plumosite" and other sulphosalt minerals from the Herja hydrothermal vein deposit, Baia Mare district, Rumania. Geologica Carpathica, 48: 387-399.

Cordua, W.S. 2000, Doing Acid Tests on Rocks and Minerals. Rocks \& Minerals, 75: 276-277.

Ghiurcă, V. 1985a, Aus der Welt der runden jamesonite mikrokristale von Baia Mare, Rumãnien.-Zylindrische Mikrokristale. Der Aufschluss, 36: 145-150.

Ghiurcă, V. 1985b, Les habitus en rondelles. Dans le monde curieux des microcristaux de jamesonite. Minéraux et Fossiles, 120: 23-24 \& 29-30.

Ghiurcă, V. 1985c, Il mondo curioso dei micriocristali di jamesonite-tipo anulare. Rivista Mineraliogica Italiana, 4: 160-164.

Ghiurcă, V. 2005, Globular crystal aggregates in the jamesonite assemblage. Studii şi Cercetări, GeologieGeografie, 10: 41-46.

Ghiurcă, V., Moțiu, A. 1986, Curved Jamesonite crystals from Romania-transitional habit. The Mineralogical Record, 17: 375-376.

Goldschmidt, V. 1916, Atlas der Krystallformen, Band III Tafeln, 247 tafeln, Carl Winters, Heidelberg.
Hill, C.A., Forti, P. 1997, Cave minerals of the world, $2^{\text {nd }}$ ed. National Speleological Society, Huntsville, $463 \mathrm{pp}$.

Joint Committee on Powder Diffraction Standards (JCPDS) 1980, Mineral Powder Diffraction File Book, 1168 Swarthmore, $\mathrm{Pa}$.

Mârza, I., Hallbauer D.K. \& Forray, F. 2004, Hollow, nonfixed hydrothermal concretions - a mineralogical curiosity from the Herja (Baia Mare) ore deposit. Romanian Journal of Mineral Deposits, 81 (Special issue): 192-194.

Moțiu, A., Ghiurcă, V. \& Țârlea, I. 1972, Aspecte paragenetice noi în zăcămintele de sulfuri din regiunea Baia Mare (Notă). Studia Univeristatis Babeş-Bolyai, Series Geologie-Mineralogie, 17 (1): 11-19.

Rădulescu, D., Dimitrescu, R. 1966, Mineralogia topografică a României. Ed. Academiei RSR, Bucureşti, $376 \mathrm{pp}$.

Szakáll, S. (Ed.) 2002, Minerals of the Carpathians. Granit, Prague, 479 pp.

Tsipursky, S., J., Busek, P. 1993, Structure of magnesian calcite from sea urchins. American Mineralogist, 78: 775-781.

Udubaşa, G., Ilinca, G., Marincea, Ş., Săbău, G. \& Rădan S. 1992, Minerals in Romania: the state of the art 1991. Romanian Journal of Mineralogy, 74: 1-51.

Udubaşa, G., Cristea, C., Şerbănescu, A., Ghiurcă, V. \& Udubaşa, S. 1993, Fibrous sulphosalts in some ores or north Romania. Abstract Volume, Third Geological Symposium, Baia Mare, October 1993, pp. 3-4. 